\title{
Effect of Olive Oil, Lavender Oil and Placebo on Pain Intensity and Healing of Episiotomy in Women
}

\author{
Reda M. Hables \\ Department of Obstetrics and Gynecology Nursing, Faculty of Nursing, Alexandria \\ University, Egypt and College of Applied Medical Science, university of Hafer Albatin
}

\begin{abstract}
:
Introduction: Post-episiotomy discomfort and its consequences can affect maternal quality of life and mental health as well as the mother and baby relationship. Using of Lavender, olive oil was frequently prescribed and increased due to its antiseptic and healing properties. Methodology: Quasi-experimental involved 120 postpartum women admitted for labor in ElShatby Maternity Hospital, Egypt. They were randomly categorized into three groups: Group 1 (using Lavender oil), group 2 (using olive oil) and group 3 (Using vegetable oil as a placebo oil ). Participants' pain was recorded using a Visual Analogue Scale (VAS) and a Redness, Edema, Ecchymosis, Discharge Scale (REEDA). Pain was evaluated at 1d, 5 day, 9 day and 14 days following episiotomy. Results: Pain score, there was no difference at first day between three groups, while There was slight significant difference between three studied group regarding pain intensity at $\mathrm{p}$ value $<0.05$ at 5, 9, 14 day post episiotomy. The REEDA score was no difference between mean score of scale between three studied group at first day, while there was high difference between three studied groups at fifth, ninth and fourteenth day at $\mathrm{p}$ value $<0.01$. Conclusion: According to these findings, use of Lavender oil or olive oil can be effective in reducing perineal discomfort following episiotomy and improving healing of wound, but lavender oil highest benefit.
\end{abstract}

Key words: Episiotomy, Healing, Lavender, Olive, Pain, Placebo.

Vol. 20 No. 1 February, 2021 


\section{Introduction:}

Episiotomy is a surgical incision made into the perineum area that is usually done to prevent sever perinea tears that heals poorly. In 1850, it was first introduced in the United States. Episiotomy is a surgical incision of the perineum performed at the time of delivery to increase the diameter of the soft tissue pelvic outlet. Episiotomy will facilitate and expedite delivery and prevent perineal injury, if performed correctly and at appropriate times, such as dystocia, breech delivery, fetal macrosomia, prolonged second-stage labor, obstetric anal sphincter injury, and rapid delivery ${ }^{\cdot(\mathbf{1 , 2})}$

In developing countries such as Egypt, episiotomy is a common procedure to facilitate vaginal delivery. Episiotomy may result in a few different complications, including; Infection, Large tears from the incision that may extend through the anus, Bleeding and perineal hematoma, a collection of blood in the perineal tissues, Painful intercourse and Perineal pain. ${ }^{(3)}$

Perineal pain is the most common complication of episiotomy. which is experienced by approximately $30 \%$ of women within the first two weeks and $7 \%$ of women up to 3 months after delivery. The perineal pain can decrease maternal quality of life and change mother's attitude towards her infant. Delay in wound healing can lead to poor anatomical outcomes; increase the risk of infection, and ultimately lead to dangerous complications and even death. In addition, post-episiotomy scars and pain interfere with breastfeeding position and effective lactation, thereby causing a delay in the initiation of lactation ${ }^{(4)}$

The currently advocated strategy for postpartum care contains the use of complimentary non-pharmacological adjuvant therapies in aromatherapy. Aromatherapy is the usage of essential oils from plants for decreasing pain and improving patient's satisfaction. Essential oil is concentrated extracts taken from the roots, leaves, seeds or blossoms of plants Herbal sitz bath, such as lavender essential oil and olive oil, may help to prevent infection, speed up healing and offer pain release on postpartum women $^{(5,6)}$

Wound healing and pain relief can be achieved in various ways, including cryotherapy, electrical stimulation, acupuncture, laser therapy, pelvic floor muscle training exercises, epidural analgesia, as well as taking medications, such as acetaminophen, mefenamic acid, and diclofenac sodium suppositories. (7) Nonetheless, many medicines used for this purpose, especially narcotics and 
nonsteroidal anti-inflammatory drugs (NSAIDs), have such side effects as nausea, itching, and gastrointestinal bleeding. Herbal preparations are among the earliest methods adopted in episiotomy wound healing and pain relief, which have a significant advantage over chemical medicines due to their higher acceptability and lower side effects. Lavender, Lavandula angustifolia, is an herbaceous plant belonging to the mint family, effective against most of the turtleborne pathogenic bacteria ${ }^{(8)}$

Pain control with lavender essential oil" indicated that the ant nociceptive effects of lavender on controlling acute and chronic pain considerably varied among different studies due to the nature of pain and method of drug administration. Olive Oil has antibacterial properties. Olive oil contains many nutrients that can inhibit or kill harmful bacteria olive oil has antibacterial and wound healing properties. $^{(9)}$

\section{Material and Methods:}

\section{Aim of the study:}

This study aimed to investigate the effect of olive oil, lavender oil and placebo on pain intensity and healing of episiotomy in women.

\section{Research Hypothesis:}

1- Olive oil had high positive effect on pain intensity and healing of episiotomy than lavender oil

2- Lavender oil had high positive effect on pain intensity and healing of episiotomy than olive oil

\section{Subjects and methods}

\section{Study design}

A quasi experimental study used to conduct the study.

\section{Study setting}

The study conducted at El-Shatby Maternity Hospital at Alexandria University at Egypt.

\section{Subjects}

A purposive sample used to achieve the aim of this study. It includes 120 women who meet the following inclusion and exclusion criteria: Inclusion criteria women age between 20 and 35 age and follow medical regimen related episiotomy wound.

Exclusion criteria include women with ventouse cup or forceps delivery, perineal injuries including anal sphincter and anal mucosa, post-partum bleeding, retained placenta.

They were blindly allocated into three groups each group 40 women. 


\section{Tool of data collection}

Tool (I): Predesigned questionnaire:

that consists of two parts:

Part one: Demographic characteristics: It was developed by the researcher to assess women' demographic characteristics including: age, marital status, educational level, residence, employment and income

Part two: Medical history: It was developed by the researcher to assess women's medical history. It includes gravidity, parity, previous episiotomy, current type of episiotomy and causes of episiotomy.

Tool (II): Visual Analogue Scale (VAS): Adopted from Cline, Herman, Shaw and Morton, (1992) and Crichton, (2001) $)^{(10)}$. It is a $10 \mathrm{~cm}$ line with anchor statements on the left (no pain) and on the right (extreme pain). It scored as

No pain $=0$, Mild =1-3, Moderate $=4-6$,

Severe $=7-9$ and Extreme $=10$

Tool (III): The REEDA: scale is a tool for assessing perineal healing that was primarily developed by Davidson, (1974) $^{(\mathbf{1 1})}$. It includes five items related to the healing process: hyperemia, edema, ecchymosis, discharge and cooptation of the wound edges (Redness, Edema, Ecchymosis, Discharge, Approximation REEDA), each item ranged score from (0 to 3$)$.

\section{Healing scores:}

Good (0 - 4), Moderate (5 - 8), Mild (912) and Poor (13-15)

\section{Tools reliability:}

The reliability was done by Cronbach's Alpha coefficient test of the tool which revealed the scale is .79 for pre designed questionnaire, .84 for VAS and .87 for REEDA scale.

\section{Pilot study}

A pilot study was carried out on $10 \%$ (12) from the total number of sample (120) of population to assess the tools clarity, relevancy, feasibility, objectivity, and estimate the time needed for data collection from the questionnaire. Those subjects in the pilot study were excluded from study sample, and certain modifications were done.

\section{Ethical considerations:}

Each woman in the study was informed about the purpose and benefits of the study in the first part before starting the questionnaire, where every participant can't be starting the questionnaire without consent to participate in data collection in the current study. The women were assured that all data was used for research purpose only and each one was informed of the rights to refuse participation in the study or withdraw at any time before 
completing the questionnaire with no consequences.

\section{Administrative approval:}

An official permission was obtained from the Dean of the Faculty of Nursing, Alexandria University to collect the data after explaining the aim of the study.

\section{Field work:}

This study started in the January 2019 and ended in the end of June, 2019. Women interviewed for 10-15 minutes after delivery at the hospital stay to collect demographic and medical history data. Explain to each group way to care of episiotomy; group 1 underwent care by 10 drops of lavender essential oil $2 \%$ based lavender essential oil for each (5 liters). Group 2 by 10 drops olive oil sitz bath (5 liters) and group 3 (Placebo group) by 10 drops vegetable oil $\operatorname{sitz}$ bath $(5$ liters) for fourteenth days. After that the researchers provided clear and concise information through illustrative pamphlet for the groups included the following. Then assess the pain and healing wound through second and third tool over the course of four different measurements during the first, fifth, ninth, and fourteenth days postpartum during follow up at previous mentioned setting.

\section{Statistical Design:}

Computerized data entry and Statistical analysis were fulfilled using the Statistical Package for Social Sciences (SPSS) version 22. Descriptive and analytical statistics were used such as number, percentage, mean and standard deviation. Friedman test is the non-parametric alternative to the one-way ANOVA with repeated measures. It is used to test for differences between groups

Highly significant if $\mathrm{p}$ value $<0.01$

Significant if $\mathrm{p}$ value $<0.05$

Insignificant if $\mathrm{p}$ value $>0.05$

\section{Results:}

Table (1) revealed that mean age of olive oil, lavender and placebo group was $28.56 \pm 6.1$,

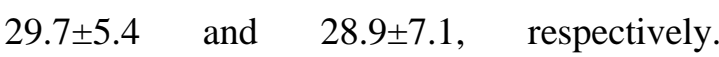
Regarding marital status, $92.5 \%$ of olive oil group was married while, $90 \%$ and $95 \%$ of lavender and placebo respectively were married. Educational level, showed that $47.5 \%, 50 \%$ and $42.5 \%$ of olive oil, lavender and placebo group respectively, had university education. Regarding residence, demonstrated that $72.5 \%, 62.5 \%$ and $75 \%$ of olive oil, lavender and placebo group from urban area. Regarding family income, 67.5\%, 60\% and $62.5 \%$ of olive oil, lavender and placebo group had enough income.

Table (2) revealed that $47.5 \%, 50 \%$ and $40 \%$ of olive oil, lavender and placebo 
group, respectively was gravidity one. Regarding parity, showed that 50\%, 50\% and $45 \%$ of olive oil, lavender and placebo group was parity one. According type of episiotomy, $45 \%, 50 \%$ and $42.5 \%$ of olive oil, lavender and placebo group was medio-lateral. Regarding causes of episiotomy, $40 \%, 32.5 \%$ and $25 \%$ of olive oil, lavender and placebo group due to prim parity.

Table (3) demonstrated that at fourteenth day, $47.5 \%$ of olive oil group had no pain and $40 \%$ had mild pain. While $52.5 \%$ of lavender oil had no pain and $42.5 \%$ had mild pain. Meanwhile $40 \%$ of placebo group had no pain and $22.5 \%$ had moderate pain. At the end, there was slight significant difference between three studied group regarding pain intensity at $\mathrm{p}$ value $<0.05$.

Table (4) detected that there was no significant difference between three studied groups at first day at $p$ value $>0.05$. While there was slight significant difference between studied groups at fifth, ninth and fourteenth day post intervention at $\mathrm{p}$ value $<0.05$.

Table (5) at fourteenth day post intervention, approved that according to redness, $17.5 \%, 17.5 \%$ and $32.5 \%$ of olive oil, lavender and placebo group suffered from moderate level. According to edema, $25 \%, 42.5 \%$ and $35 \%$ of olive oil, lavender and placebo respectively, group suffered from mild edema. Regarding discharge, $60 \%$ of lavender group had no discharge, while $50 \%$ of olive oil had no discharge but $47.5 \%$ of placebo group had none discharge. According approximation $40 \%$ of lavender group had closed wound, while $45 \%$ of placebo group had mild separation. Regarding total REEDA scale, $52.5 \%$ of lavender group had good healing, while $45 \%$ of olive oil group had good healing, but $37.5 \%$ of placebo group had moderate healing, so there was high significant difference at $\mathrm{p}$ value $<0.01$. where group lavender oil is most better result than olive oil, again group of olive oil is batter than placebo group in healing score.

Table (6) revealed that there was no significant difference between three studied groups at first day post intervention. While there was slight significant difference between studied groups at fifth, ninth and fourteenth day related edema and approximation at $p$ value <0.05. Meanwhile, there was high significant difference between three studied groups at fourteenth day related discharge and ecchymosis at $\mathrm{p}$ value $<0.01$. Regarding total REEDA scale, there was no difference between mean score of scale between three studied group at first day, while there was high difference between three studied groups at fifth, ninth and fourteenth day at $p$ value $<0.01$. 
Table (1) Number and percent distribution of studied groups according to their demographic characteristics

\begin{tabular}{|c|c|c|c|c|c|c|c|}
\hline \multirow[t]{2}{*}{ Items } & \multicolumn{2}{|c|}{$\begin{array}{l}\text { Olive oil } \\
(N=40)\end{array}$} & \multicolumn{2}{|c|}{$\begin{array}{c}\text { Lavender oil } \\
(\mathrm{N}=\mathbf{4 0})\end{array}$} & \multicolumn{2}{|c|}{$\begin{array}{l}\text { Placebo } \\
(\mathrm{N}=40)\end{array}$} & \multirow{2}{*}{$\underset{\text { test }}{\text { Friedman }}$} \\
\hline & $\mathbf{N}$ & $\%$ & $\mathbf{N}$ & $\%$ & $\mathbf{N}$ & $\%$ & \\
\hline \multicolumn{8}{|l|}{ Age: } \\
\hline $20-<25$ & 7 & 17.5 & 8 & 20 & 7 & 17.5 & \multirow{4}{*}{$\begin{array}{l}1.056 \\
0.068\end{array}$} \\
\hline $25-<30$ & 13 & 32.5 & 15 & 37.5 & 12 & 30 & \\
\hline $30-35$ & 20 & 50 & 17 & 42.5 & 21 & 52.5 & \\
\hline Mean S.D & \multicolumn{2}{|c|}{$28.56 \pm 6.1$} & \multicolumn{2}{|c|}{$29.7 \pm 5.4$} & \multicolumn{2}{|c|}{$28.9 \pm 7.1$} & \\
\hline \multicolumn{8}{|l|}{ Marital status: } \\
\hline Married & 37 & 92.5 & 36 & 90 & 38 & 95 & 2.031 \\
\hline Divorced & 3 & 7.5 & 2 & 5 & 1 & 2.5 & 0.057 \\
\hline Widow & 0 & 0 & 2 & 5 & 1 & 2.5 & \\
\hline \multicolumn{8}{|l|}{ Educational level: } \\
\hline Preparatory & 4 & 10 & 5 & 12.5 & 6 & 15 & 0.968 \\
\hline Secondary & 14 & 35 & 12 & 30 & 13 & 32.5 & 0.144 \\
\hline University & 19 & 47.5 & 20 & 50 & 17 & 42.5 & \\
\hline Higher education & 3 & 7.5 & 3 & 7.5 & 4 & 10 & \\
\hline \multicolumn{8}{|l|}{ Residence: } \\
\hline Urban & 29 & 72.5 & 25 & 62.5 & 30 & 75 & 2.218 \\
\hline Rural & 11 & 27.5 & 15 & 37.5 & 10 & 25 & 0.052 \\
\hline \multicolumn{8}{|l|}{ Employment: } \\
\hline Employee & 17 & 42.5 & 16 & 40 & 19 & 47.5 & 1.008 \\
\hline Unemployed & 23 & 57.5 & 24 & 60 & 21 & 52.5 & 0.097 \\
\hline \multicolumn{8}{|l|}{ Income: } \\
\hline Enough & 27 & 67.5 & 24 & 60 & 25 & 62.5 & 1.305 \\
\hline Not enough & 13 & 32.5 & 16 & 40 & 15 & 37.5 & 0.071 \\
\hline
\end{tabular}


Table (2) Number and percent distribution of studied groups according to their medical history

\begin{tabular}{|c|c|c|c|c|c|c|c|}
\hline \multirow[t]{2}{*}{ Items } & \multicolumn{2}{|c|}{$\begin{array}{l}\text { Olive oil } \\
(\mathrm{N}=40)\end{array}$} & \multicolumn{2}{|c|}{$\begin{array}{l}\text { Lavender oil } \\
\qquad(\mathrm{N}=\mathbf{4 0})\end{array}$} & \multicolumn{2}{|c|}{$\begin{array}{l}\text { Placebo } \\
(\mathrm{N}=40)\end{array}$} & \multirow[t]{2}{*}{$\underset{\text { test }}{\text { Friedman }}$} \\
\hline & $\mathbf{N}$ & $\%$ & $\mathbf{N}$ & $\%$ & $\mathbf{N}$ & $\%$ & \\
\hline Gravidity: & & & & & & & \\
\hline 1 & 19 & 47.5 & 20 & 50 & 16 & 40 & 1.720 \\
\hline 2 & 14 & 35 & 15 & 37.5 & 16 & 40 & 0.054 \\
\hline 3 & 7 & 17.5 & 5 & 12.5 & 8 & 20 & \\
\hline Parity: & & & & & & & \\
\hline 1 & 20 & 50 & 20 & 50 & 18 & 45 & 0.994 \\
\hline 2 & 13 & 32.5 & 16 & 40 & 16 & 40 & 0.201 \\
\hline 3 & 7 & 17.5 & 4 & 10 & 6 & 15 & \\
\hline Previous episiotomy: & & & & & & & \\
\hline Yes & 10 & 25 & 9 & 22.5 & 8 & 20 & 1.006 \\
\hline No & 30 & 75 & 31 & 77.5 & 32 & 80 & 0.081 \\
\hline $\begin{array}{l}\text { Current type of } \\
\text { episiotomy: }\end{array}$ & & & & & & & \\
\hline Medio-lateral & 18 & 45 & 20 & 50 & 17 & 42.5 & 2.101 \\
\hline Median & 9 & 22.5 & 7 & 17.5 & 13 & 32.5 & 0.0531 \\
\hline Lateral & 10 & 25 & 11 & 27.5 & 10 & 25 & \\
\hline J-shape & 3 & 7.5 & 2 & 5 & 0 & 0 & \\
\hline Causes of episiotomy: & & & & & & & \\
\hline Prim parity & 16 & 40 & 13 & 32.5 & 10 & 25 & \\
\hline Large baby & 8 & 20 & 12 & 30 & 16 & 40 & 3.068 \\
\hline Prolonged $2^{\text {nd }}$ stage & 9 & 22.5 & 11 & 27.5 & 6 & 15 & $0.042 *$ \\
\hline Shoulder dystocia & 7 & 17.5 & 4 & 10 & 8 & 20 & \\
\hline
\end{tabular}


Table (3) Number and percent distribution of the studied subjects according to their pain intensity post the intervention at fourteenth day

\begin{tabular}{|c|c|c|c|c|c|c|c|c|}
\hline \multirow{2}{*}{ Items } & & \multicolumn{2}{|c|}{ Olive oil } & \multicolumn{2}{|c|}{ Lavender oil } & \multicolumn{2}{|c|}{ Placebo } & \multirow[t]{2}{*}{ Friedman test } \\
\hline & & $\mathbf{N}$ & $\%$ & $\mathbf{N}$ & $\%$ & $\mathbf{N}$ & $\%$ & \\
\hline No pain $=0$ & & 19 & 47.5 & 21 & 52.5 & 16 & 40 & 3.987 \\
\hline Mild $=1-3$ & & 16 & 40 & 17 & 42.5 & 15 & 37.5 & $0.038 *$ \\
\hline Moderate $=4-6$ & & 5 & 12.5 & 2 & 5 & 9 & 22.5 & \\
\hline Severe & $=7-9$. & 0 & 0 & 0 & 0 & 0 & 0 & \\
\hline Extreme $=10$ & & 0 & 0 & 0 & 0 & 0 & 0 & \\
\hline
\end{tabular}

Table (4) Compare mean between studied groups according pain score

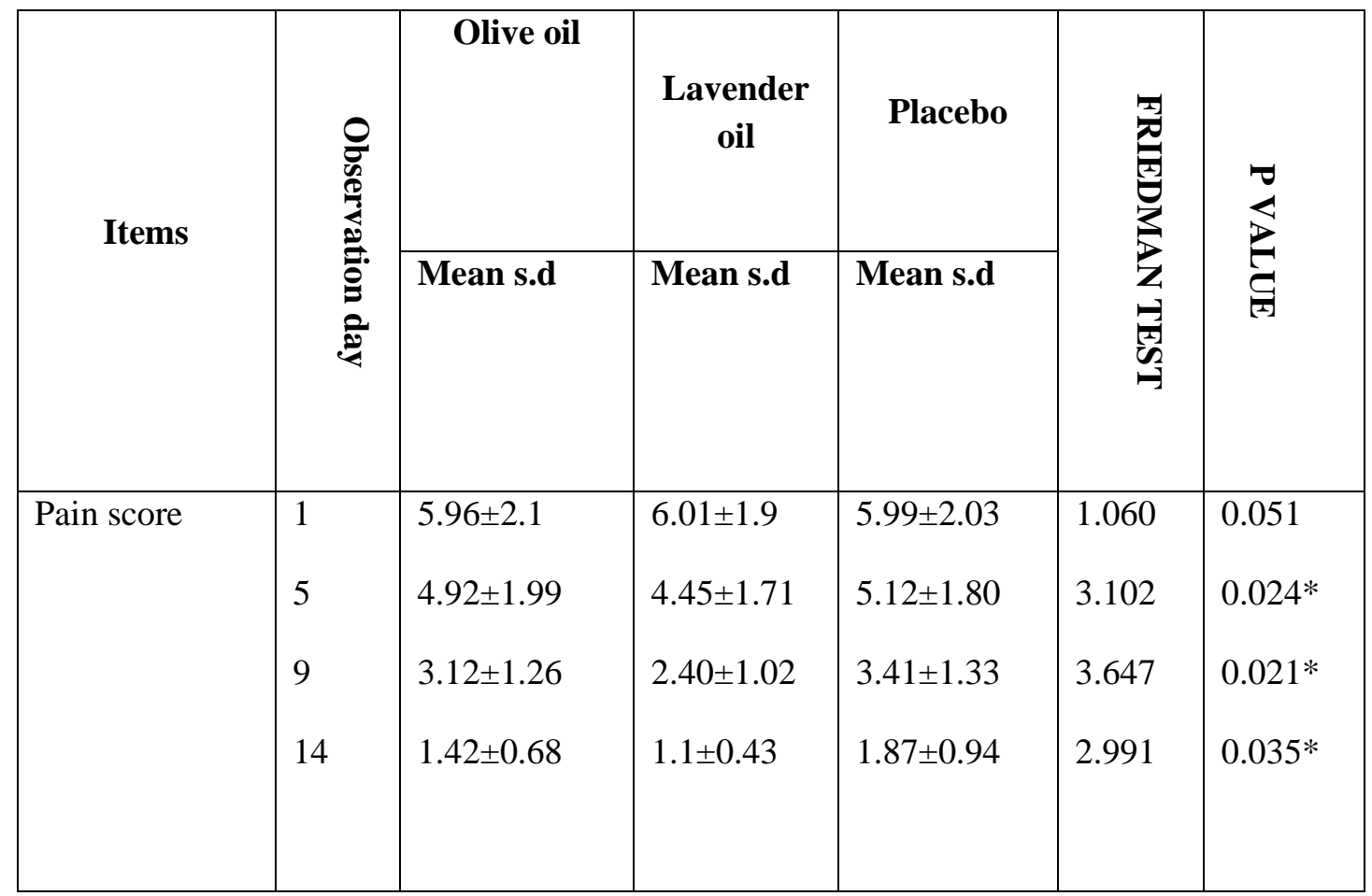


Table (5) Number and percent distribution of the studied subjects according to healing of their episiotomy using REEDA scale at fourteenth day

\begin{tabular}{|c|c|c|c|c|c|c|c|}
\hline \multirow[t]{2}{*}{ Items } & \multicolumn{2}{|c|}{$\begin{array}{l}\text { Olive oil } \\
(\mathrm{N}=40)\end{array}$} & \multicolumn{2}{|c|}{$\begin{array}{l}\text { Lavender oil } \\
\qquad(\mathrm{N}=\mathbf{4 0})\end{array}$} & \multicolumn{2}{|c|}{$\begin{array}{l}\text { Placebo } \\
(\mathrm{N}=40)\end{array}$} & \multirow[t]{2}{*}{ Friedman test } \\
\hline & $\mathbf{N}$ & $\%$ & $\mathbf{N}$ & $\%$ & $\mathbf{N}$ & $\%$ & \\
\hline \multicolumn{8}{|l|}{ Redness: } \\
\hline None & 13 & 32.5 & 16 & 40 & 12 & 30 & \\
\hline Mild & 18 & 45 & 17 & 42.5 & 11 & 27.5 & 5.168 \\
\hline Moderate & 7 & 17.5 & 7 & 17.5 & 13 & 32.5 & $.008 * *$ \\
\hline Severe & 2 & 5 & 0 & 0 & 4 & 10 & \\
\hline \multicolumn{8}{|l|}{ Edema: } \\
\hline None & 15 & 37.5 & 14 & 35 & 9 & 22.5 & \\
\hline Mild & 10 & 25 & 17 & 42.5 & 14 & 35 & 3.562 \\
\hline Moderate & 12 & 30 & 8 & 20 & 11 & 27.5 & $.011^{*}$ \\
\hline Severe & 3 & 7.5 & 1 & 2.5 & 6 & 15 & \\
\hline \multicolumn{8}{|l|}{ Ecchymosis: } \\
\hline None & 14 & 35 & 19 & 47.5 & 12 & 30 & \\
\hline Mild & 17 & 42.5 & 15 & 37.5 & 10 & 25 & 6.002 \\
\hline Moderate & 8 & 20 & 6 & 15 & 14 & 35 & $.007 * *$ \\
\hline Severe & 1 & 2.5 & 0 & 0 & 4 & 10 & \\
\hline \multicolumn{8}{|l|}{ Discharge: } \\
\hline None 0 & 20 & 50 & 24 & 60 & 19 & 47.5 & \\
\hline Mild1 & 13 & 32.5 & 12 & 30 & 10 & 25 & 5.264 \\
\hline Moderate2 & 7 & 17.5 & 4 & 10 & 10 & 25 & $.008 * *$ \\
\hline Severe3 & 0 & 0 & 0 & 0 & 1 & 2.5 & \\
\hline \multicolumn{8}{|l|}{ Approximation: } \\
\hline None/closed & 15 & 37.5 & 16 & 40 & 15 & 37.5 & \\
\hline Mild separation & 22 & 55 & 23 & 57.5 & 18 & 45 & 2.897 \\
\hline Moderate separation & 3 & 7.5 & 1 & 2.5 & 7 & 17.5 & $.023^{*}$ \\
\hline Severe separation & 0 & 0 & 0 & 0 & 0 & 0 & \\
\hline Total scale: & & & & & & & \\
\hline Good healing & 18 & 45 & 21 & 52.5 & 16 & 15 & \\
\hline Moderated healed & 17 & 42.5 & 16 & 40 & 15 & 37.5 & 4.067 \\
\hline Mildly healed & 5 & 12.5 & 0 & 7.5 & 8 & 20 & $.009 * *$ \\
\hline Poor healed & 0 & 0 & & 0 & 1 & 2.5 & \\
\hline
\end{tabular}


Table (6) Mean score between studied groups according to healing of episiotomy using REEDA scale

\begin{tabular}{|c|c|c|c|c|c|c|}
\hline \multirow{2}{*}{ Items } & \multirow{2}{*}{ 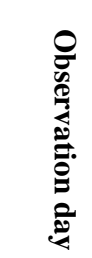 } & Olive oil & Lavender oil & Placebo & \multicolumn{2}{|c|}{ Friedman test } \\
\hline & & Mean s.d & Mean s.d & Mean s.d & Test & $\mathrm{P}$ value \\
\hline Redness & $\begin{array}{l}1 \\
5 \\
9 \\
14\end{array}$ & $\begin{array}{l}2.78 \pm 1.01 \\
2.11 \pm 1.20 \\
1.64 \pm 0.96 \\
0.95 \pm 0.26\end{array}$ & $\begin{array}{l}2.81 \pm 0.99 \\
1.97 \pm 0.87 \\
1.21 \pm 0.65 \\
0.77 \pm 0.29\end{array}$ & $\begin{array}{l}2.79 \pm 1.20 \\
2.46 \pm 0.96 \\
2.01 \pm 0.88 \\
1.50 \pm 0.34\end{array}$ & $\begin{array}{l}0.968 \\
3.684 \\
4.963 \\
5.168\end{array}$ & $\begin{array}{l}0.087 \\
0.011 * \\
0.009 * * \\
0.008 * *\end{array}$ \\
\hline Edema & $\begin{array}{l}1 \\
5 \\
9 \\
14\end{array}$ & $\begin{array}{l}2.41 \pm 1.33 \\
1.99 \pm 0.96 \\
1.46 \pm 0.88 \\
1.07 \pm 0.30\end{array}$ & $\begin{array}{l}2.43 \pm 1.04 \\
1.70 \pm 0.85 \\
1.28 \pm 0.71 \\
0.90 \pm 0.24\end{array}$ & $\begin{array}{l}2.48 \pm 0.99 \\
2.10 \pm 1.01 \\
1.74 \pm 0.61 \\
1.35 \pm 0.39\end{array}$ & $\begin{array}{l}1.002 \\
2.961 \\
3.135 \\
3.562\end{array}$ & $\begin{array}{l}0.069 \\
0.024 * \\
0.017 * \\
0.011 *\end{array}$ \\
\hline Ecchymosis & $\begin{array}{l}1 \\
5 \\
9 \\
14\end{array}$ & $\begin{array}{l}2.30 \pm 1.40 \\
1.96 \pm 1.14 \\
1.37 \pm 0.74 \\
0.90 \pm 0.21\end{array}$ & $\begin{array}{l}2.26 \pm 1.60 \\
1.53 \pm 1.02 \\
1.14 \pm 0.79 \\
0.67 \pm 0.36\end{array}$ & $\begin{array}{l}2.21 \pm 1.39 \\
2.00 \pm 1.06 \\
1.66 \pm 0.97 \\
1.25 \pm 0.27\end{array}$ & $\begin{array}{l}1.044 \\
3.106 \\
2.946 \\
6.002\end{array}$ & $\begin{array}{l}0.051 \\
0.010 * \\
0.021 * \\
.007 * *\end{array}$ \\
\hline Discharge & $\begin{array}{l}1 \\
5 \\
9 \\
14\end{array}$ & $\begin{array}{l}2.10 \pm 1.00 \\
1.68 \pm 1.02 \\
1.34 \pm 0.64 \\
0.67 \pm 0.14\end{array}$ & $\begin{array}{l}2.16 \pm 1.30 \\
1.49 \pm 1.06 \\
1.06 \pm 0.74 \\
0.5 \pm 0.11\end{array}$ & $\begin{array}{l}2.05 \pm 0.99 \\
1.70 \pm 0.86 \\
1.40 \pm 0.66 \\
0.82 \pm 0.31\end{array}$ & $\begin{array}{l}1.303 \\
3.067 \\
2.901 \\
5.264\end{array}$ & $\begin{array}{l}0.056 \\
0.011 * \\
0.020 * \\
.008 * *\end{array}$ \\
\hline Approximation & $\begin{array}{l}1 \\
5 \\
9 \\
14\end{array}$ & $\begin{array}{l}2.62 \pm 1.04 \\
2.04 \pm 0.87 \\
1.46 \pm 0.94 \\
0.7 \pm 0.12\end{array}$ & $\begin{array}{l}2.59 \pm 0.97 \\
1.89 \pm 0.93 \\
1.11 \pm 0.72 \\
0.625 \pm 0.26\end{array}$ & $\begin{array}{l}2.65 \pm 1.31 \\
2.02 \pm 1.06 \\
1.68 \pm 1.01 \\
0.80 \pm 0.19\end{array}$ & $\begin{array}{l}0.968 \\
1.989 \\
2.364 \\
2.897\end{array}$ & $\begin{array}{l}0.061 \\
0.041 * \\
0.029 * \\
0.023 *\end{array}$ \\
\hline Total scale & $\begin{array}{l}1 \\
5 \\
9 \\
14\end{array}$ & $\begin{array}{l}12.21 \pm 3.68 \\
9.78 \pm 3.04 \\
7.27 \pm 2.97 \\
4.29 \pm 1.94\end{array}$ & $\begin{array}{l}12.25 \pm 4.16 \\
8.58 \pm 3.94 \\
5.80 \pm 2.26 \\
3.46 \pm 1.75\end{array}$ & $\begin{array}{l}12.18 \pm 4.20 \\
10.28 \pm 4.09 \\
8.49 \pm 3.03 \\
5.72 \pm 2.10\end{array}$ & $\begin{array}{l}1.006 \\
5.018 \\
5.694 \\
4.067\end{array}$ & $\begin{array}{l}0.055 \\
0.008 * * \\
0.007 * * \\
0.009 * *\end{array}$ \\
\hline
\end{tabular}




\section{Discussion:}

Perineal pain is the furthermost common complaint among women post-delivery. Pain results in stress and anxiety, which disturb the tissues repair process. Thus, perineal pain post-delivery lead to negative impressions on women's performance in providing care for their infants and family members (Therefore, the current study aimed to compare the three groups with respect to pain intensity. ${ }^{(\mathbf{1 2})}$

The present results showed that there was slight significant difference between three studied group regarding pain intensity at $\mathrm{p}$ value $<0.05$. Also, detected that lavender oil group had mean pain score less than olive oil, but placebo oil had highest score of pain. These results in cohort with the study conducted by Behmanesh,(2011) ${ }^{(13)}$ titled in A Clinical trial to compare the effectiveness of Lavender essential oil and olive oil at healing postpartum mother's perinea, who detected that mean pain score of olive oil group, was lower than lavender oil group. But, supported with the study performed by Sheikhan et al., (2013) $)^{(14)}$ about Episiotomy pain relief: Use of Lavender oil essence in primiparous Iranian women-Complementary Therapies in Clinical Practice, who concluded their study that using of Lavender oil essence can be effective in reducing perineal discomfort following episiotomy.
Also, consistent with López, Nielsen, Solas, Ramírez and Jäger, (2017) ${ }^{(15)}$, titled in Exploring pharmacological mechanisms of lavender (Lavandula angustifolia) essential oil on central nervous system targets, who demonstrated that lavender oil had analgesic effect. Also, agreement with the study conducted by Moradi, Niazi, Mazloumi, Mousavi and Lopez,( 2020) ${ }^{(16)}$ about effect of lavender on episiotomy wound healing and pain relief: a systematic review, who recommended lavender oil as the treatment of choice in episiotomy wound healing and pain relief.

Also, consistent with the study performed by Rezaie-Keikhaie et al., (2019) ${ }^{(17)}$ about effect of aromatherapy on postpartum complications: a systematic review, who presented that essential oil can use to improvement of different psychological and physical symptoms. Meanwhile, supported with Essa, Mohamed and Kandeel, (2020) ${ }^{(\mathbf{1 8 )}}$ titled in effect of aloe vera gel versus normal saline on pain relief and healing process of episiotomy, who recorded essential oils such as lavender, olive, turmeric, Aloe Vera, were reported as the less costs, most effective methods in wound healing and attenuation of episiotomy pain. And, consistent with the study performed by

Behmanesh,

Aghamohammadi, 
Zeinalzadeh and Khafri, (2013) ${ }^{(19)}$ about effects of olive oil sitz bath on improvement of perineal injury after delivery, who revealed that pain intensity was lower in the olive oil group on days 5 and 10 after delivery.

Complications of episiotomy include hemorrhage, infection, wound dehiscence, obstetric anal sphincter injuries, necrotizing fasciitis and delayed ones like dyspareunia, scar endometriosis and fistula Mittal, (2020) ${ }^{(\mathbf{2 0})}$. The typical healing time for an episiotomy is around 4 to 6 weeks depending on the size of the incision and the type of suture material used to close the wound Aydın Besen and Rathfisch, (2020) ${ }^{(21)}$.

According wound healing, by using REEDA scale, the current study revealed that slight more than half $(52 \%)$ of lavender group had good healing, while Less than half (45\%) of olive oil group had good healing, but more than one third $(37.5 \%)$ of placebo group had moderate healing, so there was high difference between three studied groups at fifth, ninth and fourteenth day at $\mathrm{p}$ value $<0.01$. These results supported with the study conducted by Sari, Hamranani and Sawitri, (2020) (22) titled in Effectiveness of lavender sitzbath therapy on epissiorraphy of postpartum mother, who demonstrated that lavender sitzbath therapy had a significant relationship in the healing process of primiparous mother. Agreement with the study performed by Mori, Kawanami, Kawahata and Aoki, 2016 ${ }^{(23)}$ titled in wound healing potential of lavender oil by acceleration of granulation and wound contraction through induction of TGF- $\beta$ in a rat model, who reported that lavender oil improvement wound healing. Meanwhile, cohort with the study performed by Kaur and Kaur, (2016) ${ }^{(24)}$ about a study to assess the effectiveness of lavender oil versus povidine iodine on healing of episiotomy wound among postnatal mothers, who detected that Lavender oil helps in episiotomy wound healing in experimental group from day 1 to day 5 . Lavender oil was more effective in episiotomy wound healing from day 1 to day 3 as compared to povidine-iodine.

Also, consistent with Shayan et al., $\mathbf{( 2 0 2 0}^{(\mathbf{2 5})}$ about the effect of olive oil and honey combination on episiotomy wound healing and pain relief: a randomized clinical trial, who showed that using honey and olive oil combination improves episiotomy wound healing and also relieves its' associated pain. Also, cohort with the study conducted by Mahboubi et 
al., (2016) (26) titled in the effect of oliveria decumbens and pelargonium graveolens on healing of infected skin wounds in mice, who revealed that olive oil, had positive effect on wound healing. And, supported with the study by Kapoor, (2018) (27) about a comparative study to assess the effectiveness of medicated and non-medicated sitz bath on episiotomy wound healing among postnatal mothers, who detected that sitz bath with essential oil had same effect of medicated sitz bath on episiotomy healing. But, disagreement with the study by Behmanesh et al., 2011, (28) who detected that there was no significant difference between lavender oil and olive oil group at healing of episiotomy .

\section{Conclusion:}

To conclude, According to these findings, use of Lavender oil or olive oil can be effective in reducing perineal discomfort following episiotomy and improving healing of wound, but lavender oil had the highest benefit.

\section{Recommendations:}

-This study suggests that lavender oil and olive oil added to routine water sitz bath for post-episiotomy care

-Further study about effect of lavender oil and olive oil on wound healing with increasing sample size and different settings.

-Assess factors affecting on pain and wound healing for post-episiotomy women

\section{References:}

1- Klein, M. C., and Kaczorowski, J. Routine use of episiotomy with forceps should not be encouraged. CMAJ, 2020; 192(8), E190-E190.

2- Zilberman, A., Sheiner, E., Barrett, O., Hamou, B., and Silberstein, T. Correction to: Once episiotomy, always episiotomy?. Archives of gynecology and obstetrics, 2019; 300(2), 489

3- Abbas, A. M., Kamel, F. M., and Salman, S. A. Prophylactic episiotomy for prevention of perineal tears in women with high striae gravidarum score. American Journal of Obstetrics and Gynecology, 2019; 220(1), S436.

4- Åhlund, S., Rådestad, I., Zwedberg, S., and Lindgren, H. Perineal pain the first year after childbirth and uptake of post-partum check-up-A Swedish cohort study. Midwifery, 2019; 78, 8590.

5- Vaziri, F., Shiravani, M., Najib, F. S., Pourahmad, S., Salehi, A., 
andYazdanpanahi, Z. Effect of lavender oil aroma in the early hours of postpartum period on maternal pains, fatigue, and mood: a randomized clinical trial. International journal of preventive medicine, $2017 ; 8$.

6- Singh, S., Thakur, T., Chandhiok, N., and Dhillon, B. S. Pattern of episiotomy use and its immediate complications among vaginal deliveries in 18 tertiary care hospitals in India. The Indian journal of medical research, 2016; 143(4), 474.

7- Crichton, N. Visual analogue scale (VAS). J Clin Nurs, 2001; 10(5), 706-6.

8- Kaddoura, R., DeJong, J., Zurayk, H., Kabakian, T., Abbyad, C., and Mirza, F. G. Episiotomy practice in the Middle East: A Lebanese teaching tertiary care centre experience. Women and Birth, 2019; 32(2), e223e228.

9- Escuriet, R., Pueyo, M. J., GarciaLausin, L., Obregón, N., PerezBotella, M., López, J. M., and LeónLarios, F. Vaginal Delivery Care, Episiotomy Performance and Examination of Severe Perineal Tears: Cross-Sectional Study in 43 Public Hospitals. Obstet. Gynecol. Int. J., 2017; 7(6).
10- Cline, M. E., Herman, J., Shaw, E. R., and Morton, R. D. Standardization of the visual analogue scale. Nursing research.Sari, D. P., 1992.

11-Davidson N. REEDA: evaluating postpartum healing. J Nurse Midwifery. 1974;19:6-

12-Grabie, Y., Jamil, N. Z., Schwob, J., and Uryash, A. A Novel Therapeutic in the Management of PostEpisiotomy Pain [02M]. Obstetrics and Gynecology, 2020;135, 135S.

13-Behmanesh, F., Tofighi, M., Delavar, M. A., Zeinalzadeh, M., Moghadamnia, A. A., and Khafri, S. A. A Clinical trial to compare the effectiveness of Lavender essential oil and olive oil at healing postpartum mother's. HealthMED, 2011;5(6), 1512-16

14-Sheikhan, F., Jahdi, F., Khoei, E. M., Shamsalizadeh, N., Sheikhan, M., and Haghani, H. Episiotomy pain relief: Use of Lavender oil essence in primiparous Iranian womenComplementary Therapies in Clinical Practice,2014;Vol. 18, 1-ISBN: 17443881-p. 66-70

15-López, V., Nielsen, B., Solas, M., Ramírez, M. J., and Jäger, A. K. Exploring pharmacological 
mechanisms of lavender (Lavandula angustifolia) essential oil on central nervous system targets. Frontiers in pharmacology, 2017; 8, 280L

16- Moradi, M., Niazi, A., Mazloumi, E., Mousavi, S. F., and Lopez, V. Effect of Lavender on Episiotomy Wound Healing and Pain Relief: A Systematic Review. Evidence Based Care, 2020;10(1), 61-69

17- Rezaie-Keikhaie, K., HastingsTolsma, M., Bouya, S., Shad, F. S., Sari, M., Shoorvazi, M., and Balouchi, A. Effect of aromatherapy on postpartum complications: A systematic review. Complementary therapies in clinical practice. 2019.

18- Essa, R., Mohamed, A. P. N., and Kandeel, H. Effect of Aloe Vera Gel versus Normal Saline on Pain Relief and Healing Process of Episiotomy. 2020.

19-Behmanesh F, Aghamohammadi A, Zeinalzadeh M, Khafri S. Effects of olive oil sitz bath on the improvement of perineal injury after delivery. Koomesh Mittal, M. Episiotomy. In Labour Room Emergencies 2020; (pp. 271-281).

20- Springer, Singapore.Aydın Besen, M., and Rathfisch, G. The effect of suture techniques used in repair of episiotomy and perineal tear on perineal pain and dyspareunia. Health Care for Women International, 2020;41(1), 22-37.

21-Cline, M. E., Herman, J., Shaw, E. R., and Morton, R. D. Standardization of the visual analogue scale. Nursing research.Sari, D. P. 1992.

22- Hamranani, S. S. T., and Sawitri, E. Effectiveness of lavender sitzbath therapy on epissiorraphy of postpartum mother. In Journal of Physics: Conference Series, 2020; (Vol. 1517, p. 012046).

23-Mori, H. M., Kawanami, H., Kawahata, H., and Aoki, M. Wound healing potential of lavender oil by acceleration of granulation and wound contraction through induction of TGF$\beta$ in a rat model. BMC complementary and alternative medicine, 2016;16(1), 144.

24-Kaur, H., and Kaur, B. A Study to Assess the Effectiveness of Lavender Oil Versus Povidine Iodine on Healing of Episiotomy Wound among Postnatal Mothers. Indian Journal of Public Health Research and Development, 2016; 7(2), 5-10. 
25- Sheikhan, F., Jahdi, F., Khoei, E. M., Shamsalizadeh, N., Sheikhan, M., and Haghani, H. Episiotomy pain relief: Use of Lavender oil essence in primiparous Iranian womenComplementary Therapies in Clinical Practice,2014;Vol. 18, 1-ISBN: 17443881-p. 66-70.,1

26- Mahboubi, M., Feizabadi, M. M., Khamechian, T., Kazempour, N., Zadeh, M. R., Sasani, F., and Bekhradi, M. The effect of Oliveria decumbens and Pelargonium graveolens on healing of infected skin wounds in mice. World journal of plastic surgery, 2016; 5(3), 259.

27-Kapoor, J. A comparative study to assess the effectiveness of medicated and non medicated sitz bath on episiotomy wound healing among postnatal mothers at govt Smgs maternity hospital Jammu JK. International Journal of Pregnancy and Child Birth, 2018;4(4).

28-Behmanesh, F., Aghamohammadi, A., Zeinalzadeh, M., and Khafri, S. Effects of olive oil sitz bath on improvement of perineal injury after delivery. Koomesh, 2013;14(3).L 